\title{
Social and Legal Aspects of Eutanasia Regulation: International Experience
}

\author{
Sergij S. Vitvitskiy, Oleksandr N. Kurakin, Pavlo S. Pokataev, Oleksii M. Skriabin, Dmytro B. Sanakoiev, \\ ${ }^{1}$ Associate Professor, Doctor of Laws, Rector of Donetsk Law Institute of the Ministry of Internal Affairs of \\ Ukraine, KryvyiRih, Ukraine, ${ }^{2}$ Associate Professor, Doctor of Law, Deputy Director for Educational and Research \\ Activities of the Kryvyi Rih Educational and Scientific Institute of the Ministry of Internal Affairs of Ukraine, \\ Kryvyi Rih, Ukraine, ${ }^{3}$ Professor, Doctor of Science in Public Administration, Doctor of Laws, First Vice-Rector, \\ Classical Private University, Zaporizhzhia City, Ukraine, ${ }^{4}$ Associate Professor, Doctor of Laws, Associate \\ Professor of Criminal Law, Procedure and Criminology Department, Classical Private University, Zaporizhzhia \\ City, Ukraine, ${ }^{5}$ Associate Professor, Candidate of Juridical Sciences, Head of the Financial and Strategic \\ Investigations Department, Faculty of Training for Strategic Investigations Units, Dnipropetrovsk State University \\ of Internal Affairs, Dnipro City, Ukraine
}

\begin{abstract}
Introduction: The basic human right is the right to life, along with the issue of the right to die. Euthanasia, as the right to die, is an urgent problem, the solution of which takes place on the border of medical science and jurisprudence.

The Aim: Analyze the international experience of social and legal regulation of euthanasia.

Materials and Method: To achieve the set goal, research method such as a comparative law method, theoretical analysis, system-analytical method and a method of conclusions systematization were applied is not prohibited, but it is not legalized in Germany, Spain, France, Albania, Israel.

Conclusions: Analyzing the current international experience of euthanasia legal regulation, it stands to mention that even with the prohibition of euthanasia, there are some gaps in the legislation, whichcreate the possibility of passive euthanasia legal use by means of terminating life sustaining measures. It is important to enshrine the rules clearly regulating euthanasia in international law, otherwise this issue will be latent, and in the countries where there are legal gaps, excessive use of euthanasia will take place.
\end{abstract}

Keywords: Euthanasia, legal regulation, legalization of euthanasia, right to die.

\section{Introduction}

Life and death issues are the subject of scientific research by the specialists in various fields: philosophy, psychology, sociology, medicine and law. In modern states, the protection of civil rights and freedoms of a

\section{Corresponding Author: Skriabin O.M.}

Address: Gogol street 149, building 2, Zaporozhye City, Ukraine, 69039

e-mail: skriabinadvokat@gmail.com

Phone: +380667773733 person is one of the main issues, which is given a lot of attention. Everyone has the right to life. In this context, the issue of the human right to die arises, and from the scientific research point of view, the issue of euthanasia and its legalization is a matter of debate. Thus, there are countries in the world that have legalized euthanasia at the legislative level. However, scientists have not come to a consensus concerning legalization of euthanasia and effective legal support for the exercise of the human right to euthanasia. Therefore, it is advisable to study the legal regulation of euthanasia in foreign countries and analyze the experience of countries that have legalized euthanasia at the legislative level. 
Materials and Method. The article uses modern literature sources on the dynamics of the legal framework to study the international experience of socio-legal aspects of euthanasia regulation. To achieve the set goal, research method such as a comparative law method, theoretical analysis, system-analytical method and a method of conclusions systematization were applied.

Findings and discussion. The issue of euthanasia and its legal regulation is extremely topical today. Thus, I.V. Chekhovska notes that more and more attention is being paid to the role of humanism in clinical practice, which therefore increases interest in the study of euthanasia. This is explained both by the medicine development, which allows to fight for a human life for a long time, and the priority human right to life, which means freedom of choice, including the prolongation of life $^{1}$.

The concept of euthanasia has a pretty large number of interpretations. Thus, the pharmaceutical encyclopedia defines euthanasia as the intentional deprivation of a patient's life in order to alleviate his suffering ${ }^{2}$. In the British Encyclopedia, euthanasia is referred to as "mercy killing", which means an act or practice of painlessly putting to death persons suffering from painful and incurable disease or incapacitating physical disorders ${ }^{3}$. In the Oxford Dictionary, the concept of euthanasia means: calm and easy death; funds for it, actions for its implementation ${ }^{4}$.

In the scientific literature,euthanasia is classified by various distinctive features ${ }^{1}$ :

- by types of services provision: active, passive;

- by the method of implementation: positive, negative;

- by the expression of the patient's will: voluntary, compulsory;

- by the individuals receiving services: for adults, minors;

- by types of illness: for seriously ill patients in the thermal stage, mentally ill persons.

Let's focus on the definitions of active and passive euthanasia, because this distinguishing is significant in terms of legal regulation of its implementation. Active euthanasia is the carrying out of any actionor administration of drugs accelerating lethal outcome. Active medical euthanasia can take three forms ${ }^{5}$ and is performed:
- without the patient's consent (for example, if the patient is in a coma), when a doctor or close family members approve of the procedure instead;

- $\quad$ with the help of a doctor;

- self-euthanasia, in which the patient administers a drug by himself or turns on the device, which helps him to commit suicide.

Passive euthanasia implies non-use of drugs and non-performance of medical manipulations that would sustain the life of a seriously ill patient for a certain period of time. It is difficult to agree with this point of view, because the right to refuse medical intervention, a patient's legal right, can be exercised due to lack of consent to medical intervention, while euthanasia is a combination of one person's individual freedom and another person's responsibilities. Thus, the implementation of passive euthanasia requires certain activities on the part of the health worker, which determines the presence of a social component ${ }^{5}$.

Euthanasia issues are regulated by the international legal enactments regulating the right to life and, accordingly, relating to euthanasia. These international documents include: the Universal Declaration of Human Rights d/d December 10, 1948, the European Convention for the Protection of Human Rights and Fundamental Freedoms d/d November 4, 1950 (as amended), some international documents of medical associations, namely: Convention of the Council of Europe, 1997, Convention for the Protection of Human Rights and Dignity of the Human Being with regard to the Application of Biology and Medicine; Convention on Human Rights and Biomedicine. However, the issue of euthanasia is not directly regulated by international law, although in 1987 the 39th World Medical Assembly in Madrid adopted the Declaration on Euthanasia ${ }^{6}$.

Currently in Ukraine, euthanasia is prohibited in any form, both active and passive. It should be noted that euthanasia is not only prohibited by the current legislation of Ukraine, but its commission is considered to be a crime - premeditated murder in accordance with Part 1 of Art. 115 of the Criminal Code of Ukraine ${ }^{7}$, which is punishable by imprisonment for a term of seven to fifteen years.

Assessing the current state of legalization of the institute of euthanasia in Europe, America, Asia, it is worth noting that its enshrinement in the legislation of certain countries is an exception to the general rules, not 
a global trend. This thesis can be confirmed by the fact that both active and passive euthanasia is not prohibited in the Netherlands, Belgium, Switzerland, some US states and areas of Australia, Luxembourg. Passive euthanasia is not allowed (but not directly prohibited) in Germany, Spain, France, Albania, Israel, but these countries oppose the introduction of active euthanasia. In Japan, the issue of the possibility of legalizing the "right to die" is currently discussed ${ }^{8}$.

In the world, the practice of euthanasia is widespread in many countries. The Netherlands is a clear example. After long hesitations and negotiations, euthanasia was legalized in this country at the legislative level in 2002. In addition, suicide assistance in the Netherlands is also not punishable by law. In this case, euthanasia requires compliance with the basic requirements: the patient must be terminally ill, suffer from excruciating pain and have no chance of recovery. Thisperson must desire his death being in his right mind and insisting on it for a certain period of time. Currently, the acceptable age is 12 years old (with parental consent).

Switzerland is also a country where the right to die is enshrined in law. According to local legislation, assisting in the act of suicide is not prohibited, provided there are no personal sordid motives. Foreigners come to Switzerland for this purpose, as it is the only country in the world where euthanasia is allowed for residents of other countries ${ }^{9}$.

Belgium is a country that, following the example of the Netherlands, adopted a law legalizing euthanasia in that country as far back as in 2002. According to the Belgian Law on Euthanasia, it can only be performed by a doctor who has been supervising a terminally ill person for a long time. Belgian citizens residing in the country can only be the patients. In 2014, the King of Belgium signed an administration bill allowing child euthanasia ${ }^{10}$. In 2016, the first case of euthanasia of a minor was recorded.

In Finland and Sweden, passive euthanasia is not illegal, but the basis for its use is the free and conscious expression of the patient's will, and at the same time, similar requests, even from close family members, are legally invalid. In 2006 in Israel, a law allowing passive euthanasia came into force, while active euthanasia is prohibited $^{11}$.

In 2016, Canada lifted the ban on doctor's assisting in committing suicide for terminally ill patients. Currently, the administration bill is being formally approved. However, according to it, not all patients can get this right, but only degenerative ones, i.e. those whose tragic end is close and undeniable ${ }^{12}$.

Thus, in the countries where euthanasia is prohibited, there may be gaps in the legislation allowing doctors to take action to implement euthanasia. Thus, the analysis of Ukrainian legislation in the aspect of euthanasia regulation revealed the following shortcomings. The ban on euthanasia in Ukraine is specified in Art. 52 of Basic Legislative Principles of Ukraine on Health Care, and in part 4 of Art. 43 of this document it is noted that a patient has the right to refuse medical treatment if he has full civil capacity and is aware of the significance of his actions and can control them. Part 3 of Art. 43 of the above document stipulates that if a patient refuses medical treatment, the doctor has the right to ask for written confirmation from him, and if it is impossible to obtain it - to certify the refusal in the relevant act in the presence of witnesses. This is in line with international regulations of human rights, but allows for the legal use of passive euthanasia by means of termination of life sustaining measures that is explicitly prohibited and criminally punishable in Ukraine $^{13}$.

It should be noted that in the scientific community there are different opinions about the legalization of euthanasia, as noted by V.V. Kozhan: those who oppose euthanasia, those who support legalization, and those who speak about the permissibility of euthanasia ${ }^{14}$.

Thus, opponents of euthanasia justify its inadmissibility by the possibility of medical error regarding the incurability of the disease, misconception of the patient regarding his or her health condition, as well as making a fatal decision in an inadequate perception of the situation, the possibility of euthanasia misuse by medical staff and other people concerned ${ }^{15}$.

Proponents of euthanasia consider it to be a manifestation of the highest level of humanity in relation to the person suffering pain. They firstly refer to the human right to control his or her own destiny.

Those who support euthanasia admissibility determine the list of circumstances under which euthanasia is possible. This issue was most accurately covered by H. Romanovskyi. He identifies the material and procedural criteria, which make euthanasia possible.

Therefore, we consider the opinion of V.V. 
Kozhan to be right, who states that in most cases the civilized world opposes euthanasia in its active form. However, the issue of passive euthanasia admissibility is interesting. As it was mentioned before, the essence of passive euthanasia is the lack of treatment and medical care $^{14}$.

\section{Conclusions and Recommendations}

Given the above, we should note that there is no general consensus regarding the expediency of euthanasia legalization due to the lack of opportunity to properly determine the euthanasia legality and the possibility of euthanasia misuse by health workers. The inexpediency of euthanasia legalization is also due to the rapid development of medical technologies allowing to treat those diseases in modern realities which a few years ago were considered incurable. An analysis of the legal regulation of euthanasia in Ukraine has shown that even with the prohibition of euthanasia, there are certain legislative gaps, which create the possibility of passive euthanasia legal use by terminating life sustaining measures. Imperfect legislation raises the issue of the need for doctors to not only have high profession skills and carefully document their actions, but to be legally competent specialists.Therefore, it is important to enshrine the rules clearly regulating euthanasia in the international law. Without a clear criminal regulation of euthanasia, the issue will remain latent, and in the countries where there are legal gaps, excessive use of euthanasia will take place due to economic benefits.

Conflict of Interest: None

Source of Funding: Authors

Ethical Clearance: Yes

\section{References}

1. Chekhovska I.V., Bilousyuk V.V. Legal regulation of euthanasia: international experience. International Legal Bulletin: current issues (theory and practice). 2019; 14: 23-33.

2. Pharmaceutical encyclopedia. [Internet]. Pharmencyclopedia.com. 2020. [cited 05 December 2020]. Available from: https://www. pharmencyclopedia.com.ua

3. Encyclopedia Britannica. [Internet].Britannica.com 2020. [cited 05 December 2020]. Available from: https://www.britannica.com/search
4. Fundamentals of Health Legislation № 2801XII. (1992, November 19). Verkhovna Rada of Ukraine. [Internet]. Zakon.rada.gov 2020. [cited 02 December 2020]. Available from: https://zakon. rada.gov.ua/laws/show/2801-12

5. Rachels J. Active and passive useofeuthanasia. [Internet]. Sites.ualberta.ca 1975. [cited 05 December 2020]. Available from: https://sites. ualberta. ca/ bleier/Rachels_Euthanasia.pdf

6. Gaidaichuk I.V. Human right to euthanasia: international legal consolidation and practice. International readings on international law in memory of Professor P.E. Kazansky: materials of the fourth international. Science. conf. (Odessa, November 8-9, 2013). National University “Odessa Law Academy”. Odessa: Phoenix. 2013: 225-228.

7. Criminal Code of Ukraine. [Internet]. Zakon.rada. gov 2020. [cited 01 December 2020]. Available from: https://zakon.rada.gov.ua/laws/show/234114

8. Mernik A.M., Lukash E.Yu. Legalization of the Institute of Euthanasia in Ukraine: A Theoretical and Legal Approach. Legal Scientific Electronic Journal. 2019: 3: 16-19.

9. Sukholutsky A., Entin B., Samsonova T., Zhukova $\mathrm{N}$. How to treat euthanasia in otherscountries? [Internet]. Echo.msk 2013. [cited 01 December 2020]. Available from: http://www.echo.msk.ru/ blog/roadmap/1176606-echo

10. Euthanasia in Belgium. [Internet]. Evtanazija.ru 2020. [cited 01 December 2020]. Available from: https://evtanazija.ru/belgiya

11. Rapaeva M.V. Euthanasia in modern society and prospects for its feasibility in Ukraine. Legal Science. 2014;12: 183-190.

12. Quill T.E., Lo B. Brock D. W. Palliative options of last resort: comparison of voluntarily stopping eating and drinking, terminal sedation, physician assisted suicide, and voluntary active euthanasia. [Internet]. Ncbi.nlm.nih.gov 1997. [cited 011 November 2020]. Available from: https://www. ncbi.nlm.nih.gov/pubmed/9403426

13. Khimchenko S.A. On the issue of ethical, legal and medical aspects of euthanasia: Ukrainian and Russian experience. Actual problems of politics: collection Science. Odessa: Phoenix, 2012; 46: 18-25. 
14. Kozhan V.V. Personal rights and human freedoms: general theoretical research: The dissertation on competition of a scientific degree of the candidate of legal sciences. Specialty 12.00.01. Lviv: Lviv Polytechnic National University, 2016.
15. Gora M.A. Moment of origin and content of the right to life. Bulletin of the Odessa National University. Science of law. 2014;13 (9): 46-54. 